\title{
Young Learners' Use of Social Media for Information Seeking: Exploring Core LIS Journals From 2010-2014
}

\author{
Jette Hyldegård \\ Royal School of Library and Information Science \\ Copenhagen University, Denmark. \\ tqb473@iva.ku.dk
}

\begin{abstract}
Background. Increased use of social media for information seeking and learning calls for more research and knowledge of how these emerging technologies can support students' learning.

Objectives. The focus is on recent studies of young learners' use of social media for information seeking in an academic context.

Methods. The research is based on critical reading of core library and information science (LIS) journals and a selected number of conference proceedings spanning 2010 to 2014. The examination of the selected journals and proceedings was guided by two general questions: 1) Which information seeking activities, strategies and preferences can be identified when young learners use social media for information seeking in relation to course work and other study-related work tasks? 2) What motivations can be identified among young learners for using social media for information seeking in a study context?

Results. Seven studies were identified and reviewed. According to the reported results, use of social media tends to afford certain types of behavior. Specific strategies, tactics and criteria were used when requesting and evaluating information or formulating information needs. The reported factors motivating information seeking were convenience and easy access to information, in addition to the content associated with specific social media types. Students' use of social media for information seeking was associated primarily with their private information landscape.

Contributions. The challenges of using non-traditional social sources for information seeking identified in the studies raise questions of how teachers and information professionals can educate young learners to use social media competently as information seekers and authors of information.
\end{abstract}

\section{INTRODUCTION}

In recent years a growing interest in research on social media has emerged in many disciplines in the humanities and social sciences. The development is demonstrated by an increasing number of scholars now labeling their research "social media research" and by more conferences on the topic. Use of social media has also drawn significant attention from educators with an increasing number of practitioners using social media in their teaching. This interest is further reflected by the appearance of a new International Journal of Social Media and Interactive Learning Environments (IJSMILE). 
In information science, a similar tendency of increased interest in social media has been observed. In 2011 a new International Conference on Information Science and Social Media (ISSOME, 2013) was established to discuss the role of information science in this new research area. Themes of interest are the perspectives and values that information scientists can add to the study of social media and vice versa. A recent Workshop on Information Behavior on Social Media at the Information Seeking in Context (ISIC) Conference 2014 further highlights this new interest. Social media have introduced new opportunities and challenges to LIS research and practice: the traditional conception of "user" and "author" has changed fundamentally, individuals seek and share information in new ways, and critical approaches to information have become even more crucial.

Turning to young learners, an increasing use of social media and mobile technology for course work has recently been reported (Dahlstrom, 2012; Dahlstrom, Walker and Dziuban, 2013). More undergraduate students, for example, use Twitter and social studying sites (such as CourseHero) with peers and "friends." Parallel to this tendency more researchers and practitioners are concerned with questions related to young learners' digital competences. At a national level, social media and information seeking has, for example, become one of four strategic elements in a Danish national policy paper on digital fluency and secondary schools (DEFF, 2012).

Given that social media have become a part of young peoples' digital information behavior and learning, more knowledge is needed on how and why they use social media in a study context. As suggested by White, Connaway, Lanclos, Le Cornu and Hood (2012), it is necessary to move beyond the simple dichotomy of the digital native debate to understand how emerging technologies can support students' learning. This paper focuses on recent studies of young learners' (students') use of social media for information seeking in an academic context. The results may help identify the challenges users encounter when selecting non-traditional sources for information seeking. Further, it may inform discussions of which actions teachers and information professionals might take. Given this new emerging research field in LIS, it is also critical to discuss the implications for curriculum development at information schools. This paper will contribute to the discussion of social media in information science, and serve as a stepping stone for further research and practice on social media for information seeking and learning.

\section{METHODS}

Following Fisher and Julien's approach (2009) the work reported in this paper is based on a critical reading of core LIS journals spanning the years 2010 to 2014 . The journals were selected from Fisher and Julien (2009) and from the Danish national authority list of journals within library and information science (Ministry of Higher Education and Science, 2014). The selected journals are: Annual Review of Information Science and Technology (ARIST), College \& Research Libraries, Information Research, Information Processing and Management, Journal of the American Society for Information Science Research, Journal of Documentation, Library \& Information Science Research plus proceedings from conferences such as Information Seeking in Context (ISIC), American Society for Information Science and Technology (ASIST), Information, Interaction and Impacts (i3), and the new International Conference on Information Science and Social Media (ISSOME). In addition, the journal Education and Information Technologies has been examined.

Trends in information behavior research have previously been addressed by Julien, Pecoskie and Reed (2011) spanning the years 1999-2008, and by Fisher and Julien (2009) 
spanning the years 2005-2008. Recently, a book by Beheshti and Large (2013) has addressed the information behavior of the new generation of young people. It includes a chapter by Agosto and Abbas (2013) reviewing existing research on youth and online social networking. Ahn (2011) has reviewed current theories and controversies regarding social network sites and their effect on adolescents' social and academic development.

The examination and reading of selected journals and proceedings has been guided by two general questions of interest:

1. Which information seeking activities, strategies and preferences can be identified when young learners use social media for information seeking in relation to course work and other study related work tasks?

2. What motivations can be identified among young learners for using social media for information seeking in a study context?

Inspired by Kuhlthau's work (1991; 2004), the first question concerns the individual student's searching, asking and evaluation activities when using social media to serve an information need. In addition, it includes an interest in identifying specific strategies and preferences for using social media, for example, across different social media types.

From many studies of young peoples' information seeking behavior in a study context, we know that not only cognitive factors may motivate, guide or affect behavior. Personal factors such as emotions (e.g., Kuhlthau, 1991; 2014; Nahl \& Bilal, 2007) or contextual and situational factors also influence how and why students seek information. With regard to social media, Clark, Logan, Luckin, Mee and Oliver (2009) have, for example, identified that young learners tend to use social media for course work out of school rather than in their academic context and learning space. Understanding the underlying motivations for this "digital dissonance" or other related phenomena is the focus of the second question. The examination of selected journals and proceedings has further been limited by the following definitions of young learners, social media and information seeking.

With regard to young learners, different terms and age ranges have been used in previous research on young users, for example in studies of online social networking (Agosto \& Abbas, 2013). In this paper, young learners refer to undergraduate students who are at their emergent and transitional stage of their educational lifecycle, that is, between their information habits and practices formed by secondary school/high school and the university. Results associated with students from other educational levels have been considered if relevant to the two general questions. Regarding social media, no agreement exists among researchers on the definition of the term. In line with Joosten (2012), social media is here defined as a subset of user based applications including blogs, wikis, and social networking sites such as Facebook and Youtube. Information seeking is conceptualized as a subset of information behavior (Wilson, 1999), particularly concerned with the variety of methods and activities individuals employ to discover and gain access to information and solve an information need. As shown in Figure 1, information seeking is further conceptualized as one of two core information behavior activities on a continuum between information seeking and sharing of user generated content. Different user roles are associated with the two activities, but the relation between information seeker (consumer) and creator (author) is only symbolic as both roles often can be assigned to the same individual. In this paper, the focus is on the young learner as "information seeker." 
Information seeking

(user role: information seeker/consumer)
Social media

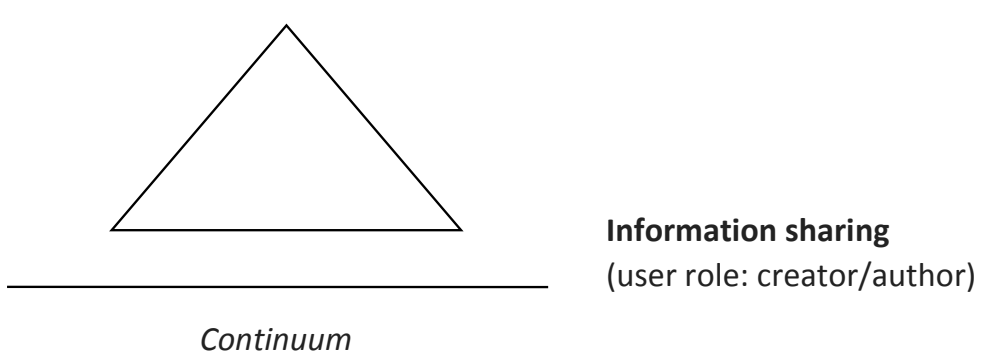

Figure 1. Conceptual model of information-behavior activities and social media

\section{RECENT RESEARCH ON YOUNG LEARNERS' USE OF SOCIAL MEDIA FOR INFORMATION SEEKING}

Seven studies were identified since 2010 investigating young learners' use of social media for information seeking and learning in relation to course work and study related tasks. Important studies may have been excluded due to the selected time span and other limitations of the examined journals and conference proceedings. The reported studies were conducted in the United Kingdom and the United States. The methods employed were primarily qualitative, and the number of participants differed from eight to several hundred people. Four of the studies concerned solely undergraduates, while the remainder concerned undergraduates and postgraduates. In one case, the study concerned users of an academic discussion site including students, faculty and professionals. The results of the studies are shortly presented below emphasizing activities and motivations. An overview of the studies is presented in the Appendix.

\section{Activities}

In all studies, social media were used by students on a daily basis. In the study by Connaway, White, Lanclos and Le Cornu (2013), use of social media for academic work was found to depend on the students' mode of behavior, for example whether they were guided by a defined goal or task (the visitor mode), or wanted to communicate and collaborate with friends and peers and demonstrate online presence (the residence mode). In the first case, social media were used functionally to serve a study related need, whereas students in the second case spent more hours sharing material and opinions online.

Wikipedia was the social media used mostly for information seeking across the seven studies. In contrast, blogs were not frequently used as information source (Kim, Sin \& YooLee, 2014). Wikipedia was used primarily for finding or acquiring background information and getting a quick overview, checking factual information, finding solutions to a problem or how-to-instructions (Kim, Yoo-Lee \& Sin, 2011; Kim, Sin \& Yoo-Lee, 2014). Social networking sites such as Facebook and LinkedIn were used as information sources to get updates, obtain opinions from others, and to track trends. In the study by Connaway et al. (2013), Wikipedia was used with a concern of its validity as students tended to assume that teachers and lecturers valued the authenticity of paper-based books higher.

In Hrastinski and Aghaee's study (2012), social media were preferred to other information sources when students needed support for quick questions and answers, coordinate group work, or retrieve information from external sources or share documents. 
Preferences for specific social media types were found to differ across gender and discipline. For example, students from humanities used video-sharing sites more than those in natural sciences (Kim, Sin \& Yoo-Lee, 2014).

Three social search tactics for information gathering were identified in Evans, Kairam and Pirolli's study (2010): targeted asking (asking friends or colleagues on email and instant messaging), network asking (e.g., by using Twitter and Facebook) and searching (e.g., by using Google and Wikipedia). When these search tactics were used in combination they were found to lead to better search outcomes and learning scores. Participants received more responses via social networking sites, but answers from private channels were more thorough as friends were more eager to give satisfying answers. Moreover, when participants processed friends' or colleagues' answers to queries, it often led to greater synthesis of task-relevant material, for example through episodes of thinking and contemplation. In addition, query composition for an unknown audience in combination with restrictions and cultural norms of "short messaging" on a social networking site generally led users to formulate queries more carefully. In this way, social media contributed positively to the reformulation and framing of the task problem. Another finding from the study was that participants tended to stick to the same networking site if it had proved useful just once before. Though learning scores were still higher for traditional Web searching than social searching, it was concluded that "other people" served as cognitive aids during search- and sense-making tasks.

Serendipitous information retrieval as investigated by Dantonio, Makri and Blanford (2012) mostly took place when relaxing. Very few students encountered relevant social media content when conducting focused searches for information. It also seemed to be a matter of being receptive to new information including content from social media. Moreover, spending time on unfocused browsing was generally regarded as a leisure activity rather than a work related activity.

Kim, Yoo-Lee and Sin (2011) and Kim, Sin and Yoo-Lee (2014) identified various effective strategies for evaluating the trustworthiness of information from different social media. Students used evaluative cues that were both external and internal to the source as well as properties of the source itself such as its physical characteristics or the length of a posting/entry. When using Wikipedia, the evaluation strategy could be to compare content with other sources or checking the quality of links or notes for progress and completeness. When using social networking sites such as Facebook, the evaluation strategy could be to check others' reactions/opinions to a posting or to check information about the author/poster. User reviews were also evaluated in a number of ways, for example by comparing consistency across reviews, or by the tone and writing style or whether the reviewer used a given product for the same purpose as the user.

\section{Motivation}

Different motivations for using social media for information seeking were reported in half of the studies. In the study by Connaway, White, Lanclos \& Le Cornu (2013), it was found that information behavior at the emerging educational stage was motivated by convenience. The students simply relied on the residency and presence of their peers when using specific social media. For example, it was important that they could contact a fellow student about an assignment using Facebook at a time that was convenient to them. In contrast, some students were uncomfortable and concerned about the addictive nature of social media and the extent to which it wasted their time. The content of social media itself also seemed to be a motivating factor for information seeking, as reported in the study by Kim, Yoo-Lee and Sin 
(2011) and Kim, Sin and Yoo-Lee (2014). Hrastinski and Aghaee's study (2012) found no educational benefits of using social media among the participants. Use of social media was associated primarily with personal needs, even if its use was related to their education.

In addition to activities and motivation, time seemed to be a constraining factor for using social media, for example for coming across information serendipitously and for getting easy access to answers from friends and peers. Further, the frequency of use of specific social network sites tended to affect reactions and attitudes among individuals regarding ease of use, usefulness, information quality and feelings (Heinrichs, Lim \& Lim, 2011). The higher the frequency of use, the more positive were the perceptions.

\section{CONCLUSION}

Based on the reported studies, use of social media for information seeking in a study context tends to afford certain types of behavior. Specific strategies, tactics and criteria were found to be employed when formulating information needs, asking for help, and evaluating the trustworthiness and value of information. The different approaches to social media were also determined by the content of the social media type itself.

Though none of the studies suggested that social media can replace traditional information sources like databases and search engines, all studies showed that social media add value and provide the information seeker with "something more." Social resources may be essential for answering certain types of queries or assisting users in their request for information in combination with powerful search engines.

Motivations for using social media by students were identified in half of the studies. The reported factors motivating information seeking were convenience and easy access to information in addition to the content associated with specific social media types. However, students' use of social media for information seeking was associated primarily with their private information landscape, in line with the findings by Clark, Logan, Luckin, Mee and Oliver (2009). Students ask friends and peers but not professors, though social media have the potential to support active learning by interactions and interventions between students and faculty (Shahsavar, 2013). Though social media have emerged as important information sources in some academic contexts, the integration of social media as part of a curriculum and a formal educational context is still limited.

\section{FURTHER RESEARCH AND PRACTICE}

Young learners' use of social media for information seeking and their educational practice have increased, but as the seven studies demonstrated new questions and issues need to be addressed by researchers and practitioners in future studies of social media in a learning context:

1. How can social media skills be transferred and used to support formal education given the nature of social media on the one hand and the quality of students' social media skills and practice on the other hand?

If no system is better than its content, then how can students' information skills and practice be improved to increase the information quality of social media? Since social media content is user generated, users should be trained in good information practice both as information seeker and information creator. As information seeker (consumer), this implies learning the art of need formulation and the search strategies and tactics for different social media, and the art of critical information evaluation. As creator (author), 
this implies learning the art and ethics of creating text in different social media, the art of tagging, and the art of writing good reviews while learning how to generate evaluation cues that may help information seekers assess the relevance of information. These could include quality criteria already known from evaluating traditional information sources or new key criteria for the evaluation of social media.

2. Which role should information professionals and teachers play in empowering students to become competent information seekers and authors of information in social media, who navigate competently across collections and platforms, and across professional and private information landscapes?

Information professionals and teachers should play a proactive role in improving the use and information quality of social media. It is not a question of replacing old skills and competences with new ones, but a matter of building upon and adjusting to the new challenges in the information environment. According to Hrastinski and Aghaee (2012), teachers play a significant role in supporting learners' move from using social media to support brief Question \& Answer and coordination, to using such media for collaborative learning. Both teachers and students need support to gain competences in finding potential educational applications, and learning the potential pedagogical and didactical benefits of social software and media (Anderson, Poellhuber \& McKerlich, 2010). Information literacy (IL) programs have traditionally focused on skills associated with the library at the educational institution. But IL programs need to move away from an orientation towards formally and institutionally integrated tools and services to an orientation towards information empowerment that may help students navigate competently across collections and platforms, and across professional and private information landscapes.

3. How should LIS curricula be designed to enable information professionals serving future generations of young learners' in using social media in the role of information seeker and information author?

LIS researchers and LIS schools play an active role in qualifying curricula and courses that address issues and challenges related to digital literacy, including information behavior in social media. But what kinds of knowledge and skills should information professional possess to serve future generations of young learners in using social media?

\section{ACKNOWLEDGEMENT}

This paper is based on a position paper for a Workshop on Information Behavior on Social Media at the Information Seeking in Context (ISIC) Conference 2014. I would like to thank the reviewers of the position paper and the present paper for their thorough, well-informed and thought provoking comments and suggestions.

\section{REFERENCES}

Agosto, D.E., \& Abbas, J. (2013). Youth and online social networking: What do we know so far? In J. Beheshti \& A. Large (Eds.), The information behavior of a new generation: Children and teens in the $21^{\text {st }}$ century (pp. 117-141). Lanham, MD: the Scarecrow Press.

Ahn, J. (2011). The effect of social network sites on adolescents' social and academic development: Current theories. Journal of the American Society for Information Science and Technology, 62(8), 1435-1445. 
Anderson, T., Poellhuber, B., \& McKerlich, R. (2010). Self paced learners meet social software: An exploration of learners' attitudes, expectations and experience. Online Journal of Distance Learning Administration, 8(3). Retrieved from http://www.westga.edu/ distance/ojdla/fall133/anderson_poellhuber_mcKerlich133.ht $\mathrm{ml}$

Clark, W., Logan, K., Luckin, R., Mee, A., \& Oliver, M. (2009). Beyond Web 2.0: Mapping the technology landscapes of young learners. Journal of Computer Assisted Learning, 25(1), 56-69.

Connaway, L.S., White, D., Lanclos, D., \& Le Cornu, A. (2013). Visitors and residents: What motivates engagement with the digital information environment? Information Research, 18(1), paper 556. Retrieved from http://InformationR.net/ir/181/paper556.html

Dahlstrom, E. (2012). ECAR study of undergraduate students and information technology, 2012. Boulder, CO: EDUCAUSE Center for Applied Research. Retrieved from http://www.educause.edu/library/resources/ecar-study-undergraduate-students-andinformation-technology-2012

Dahlstrom, E. , Walker, J.D., \& Dziuban, C. (2013). ECAR study of undergraduate students and information technology, 2013. Louisville, CO: EDUCAUSE Center for Applied Research. Retrieved from http://www.educause.edu/library/resources/ecar-studyundergraduate-students-and-information-technology-2013

Dantonio, L., Makri, S., \& Blanford, A. (2012). Coming across academic social media content serendipitously. Proceedings of the American Society for Information Science and Technology, 49(1), 1-10.

DEFF. (2012). Strategi: Digital dannelse i gymnasieskolen. Retrieved from http://www.sdu.dk/bibliotek/praktisk+information/om+biblioteket/dd-strategi

Evans, B.M., Kairam, S., \& Pirolli, P. (2010). Do your friends make you smarter? An analysis of social strategies in online information seeking. Information Processing and Management, 46, 679-692.

Fisher, K. E., \& Julien, H. (2009). Information behavior. In B. Cronin (Ed.), Annual Review of Information Science and Technology (pp. 317-358). Medford, NJ: Information Today.

Heinrichs, J. H., Lim, J-S., \& Lim, K-S. (2011). Influence of social networking site and user access method on social media evaluation. Journal of Consumer Behaviour, 10, 347355.

Hrastinski, S., \& Aghaee, N.M. (2012). How are campus students using social media to support their studies? An explorative interview study. Education and Information Technolologies, 17, 451-464.

Beseshti, J., \& Large, A. (Eds.). (2013). The information behavior of a new generation: Children and teens in the $21^{\text {st }}$ century. Lanham, MD: Scarecrow Press.

ISSOME. (2013). Call for papers: International Conference in Information Science and Social Media (ISSOME 2013). Retrieved from http://casci.umd.edu/2013/01/15/callfor-papers-issome-2013/

Joosten, T. (2012). Social media for educators: Strategies and best practices. San Francisco, CA: Jossey-Bass.

Julien, H., Pecoskie, J., \& Reed, K. (2011). Trends in information behavior research, 19992008: A content analysis. Library \& Information Science Research, 33(1), 19-24.

Kuhlthau, C.C. (1991). Inside the search process: Seeking meaning from the user's perspective. Journal of the American Society for Information Science, 42(5), 361-371. 
Kuhlthau, C.C. (2004). Seeking meaning: A process approach to library and information services $\left(2^{\text {nd }} e d\right)$. London: Libraries Unlimited.

Kim, K.S., Yoo-Lee, E.Y, \& Sin, S.C.J. (2011). Social media as information source: undergraduates' use and evaluation behaviour. Poster presented at ASIS\&T 2011 Annual Meeting, New Orleans, Louisiana, October 9-12, 2011. Retrieved from http://www.asis.org/asist2011/posters/283_FINAL_SUBMISSION.pdf

Kim, K.S., Sin, S.C.J., \& Yoo-Lee, E.Y. (2014). Undergraduates' use of social media as information sources. College \& Research Libraries, 75, 442-457.

Ministry of Higher Education and Science. (2014). Autoritetslisten for serier 2014. Retrieved from http://ufm.dk/forskning-og-innovation/statistik-og-analyser/den-bibliometriskeforskningsindikator/autoritetslister/bfi_series_2014.pdf

Nahl, D., \& Bilal, D. (Eds.). (2007). Information and emotion: The emergent affective paradigm in information behavior research and theory. Medford, NJ: Information Today.

Shahsavar, Z. (2013). Practicing socratic questioning in a blended learning environment: an innovative strategy to promote critical thinking. International Journal of Social Media and Interactive Learning Environments (IJSMILE), 1(2), 184-198.

White, D., Connaway, L.S., Lanclos, D., Le Cornu, A., \& Hood, E. (2012). Digital visitors and residents: Progress report. JISC, University of Oxford, OCLC and University of North Carolina. Retrieved from http://www.jisc.ac.uk/media/documents/projects/visitorsandresidentsinterim\%20report. pdf

Wilson, T.D. (1999). Models in information behaviour research. Journal of Documentation, 55(3), 249-270. 


\section{APPENDIX}

A chronologic overview of the seven studies from 2010-2014 on young learners' use of social media for information seeking is given below.

\begin{tabular}{|c|c|c|c|}
\hline Author(s) & Research focus & $\begin{array}{l}\text { Data } \\
\text { collection } \\
\operatorname{method}(s)\end{array}$ & $\begin{array}{l}\text { Participants/ } \\
\text { respondents }\end{array}$ \\
\hline $\begin{array}{l}\text { Kim, Sin \& } \\
\text { Yoo-Lee } \\
(2014)\end{array}$ & $\begin{array}{l}\text { Undergraduates' use of social media as information } \\
\text { sources including platforms of use, reasons for } \\
\text { using social media, and evaluation actions and cues }\end{array}$ & Survey & $\begin{array}{l}\mathrm{N}=845 \\
\text { undergraduates } \\
\text { no age range }\end{array}$ \\
\hline $\begin{array}{l}\text { Connaway } \\
(2013)\end{array}$ & $\begin{array}{l}\text { The digital information behavior of secondary } \\
\text { school students and undergraduates, including use } \\
\text { of social media. } \\
\text { Results address the emergent stage and first part of } \\
\text { a longitudinal research project (2010-2014) on } \\
\text { students and scholars digital information behavior } \\
\text { during four stages of the educational life cycle. }\end{array}$ & $\begin{array}{l}\text { Interviews and } \\
\text { diaries }\end{array}$ & $\begin{array}{l}\mathrm{N}=31 \\
\text { Secondary } \\
\text { school and } \\
\text { undergraduates } \\
18-19 \text { years }\end{array}$ \\
\hline $\begin{array}{l}\text { Dantonio, } \\
\text { Makri \& } \\
\text { Blanford } \\
(2012)\end{array}$ & $\begin{array}{l}\text { Post graduates' experiences of serendipity when } \\
\text { coming across valuable social media content for } \\
\text { academic work. }\end{array}$ & Interviews & $\begin{array}{l}\mathrm{N}=15 \\
\text { Postgraduates } \\
\text { no age range }\end{array}$ \\
\hline $\begin{array}{l}\text { Hrastinski } \\
\text { \& Aghaee } \\
(2012)\end{array}$ & $\begin{array}{l}\text { Campus students' perceptions of social media for } \\
\text { study support and academic work. }\end{array}$ & Interviews & $\begin{array}{l}\mathrm{N}=20 \\
\text { undergraduates } \\
\& \text { postgraduates } \\
19-39 \text { years }\end{array}$ \\
\hline $\begin{array}{l}\text { Heinrichs, } \\
\text { Lim \& Lim } \\
(2011)\end{array}$ & $\begin{array}{l}\text { The influence from frequency of use and access } \\
\text { form (mobile, pc etc) on how users' of an } \\
\text { academic discussion evaluate social networking } \\
\text { sites along five quality dimensions. }\end{array}$ & Online survey & $\begin{array}{l}\mathrm{N}=226 \\
\text { postgraduates, } \\
\text { employees, } \\
\text { faculty, } \\
\text { practitioners } \\
\text { no age range }\end{array}$ \\
\hline $\begin{array}{l}\text { Kim, Yoo- } \\
\text { Lee \& Sin } \\
(2011)\end{array}$ & $\begin{array}{l}\text { Undergraduates' use and evaluation of social media } \\
\text { as information sources. }\end{array}$ & Online survey & $\begin{array}{l}\mathrm{N}=446 \\
\text { undergraduates } \\
\text { no age range }\end{array}$ \\
\hline $\begin{array}{l}\text { Evans, } \\
\text { Kairam \& } \\
\text { Pirolli } \\
(2010)\end{array}$ & $\begin{array}{l}\text { The potentials of social media in helping } \\
\text { information seekers complete complex information } \\
\text { needs and search tasks. }\end{array}$ & $\begin{array}{l}\text { Talk-aloud- } \\
\text { search } \\
\text { protocols, } \\
\text { video captures }\end{array}$ & $\begin{array}{l}\mathrm{N}=8 \\
\text { undergraduates } \\
\& \text { postgraduates } \\
21-40 \text { years }\end{array}$ \\
\hline
\end{tabular}

